\title{
Connecting Emotional Spiritual Quotient and Employment Status with Performance
}

\author{
Mudayat \\ Sekolah Tinggi Ilmu Administrasi \& Manajemen Kepelabuhanan \\ Barunawati Surabaya, Indonesia
}

\begin{abstract}
The aim of this study is to examine the relationship of emotional spiritual quotient and employment status to performance either individually or jointly. Variables of emotional spiritual quotient and employment status serve as independent variables while the dependent variable is performance. The study was conducted on randomly selected 100 employees of Indonesia Port Corporation II in Surabaya Indonesia. The study quantitatively reveals that there is a positive significant relationship among variables under the following distribution of coefficient of correlation: emotional spiritual quotient to performance $=0.639$, employment status $=0.552$, and when tested together it produces coefficient of correlation $=0.932$ and coefficient of determination $=0.868$ indicating the existence of other $13.2 \%$ variables not including in the model affecting performance within the Indonesian state-owned corporation.
\end{abstract}

Keywords: emotional spiritual quotient, employment status, performance, Indonesia Port Corporation.

\section{INTRODUCTION}

Many organizations emphasize on the importance of its employees and consider them as their most important asset. In order to gain the motivation and commitment of employees towards organization, the organization has to nurture the mind, body, and soul of its employees. People's spiritual needs are often the element that is overlooked as it is generally assumed that people with high I.Q will naturally accomplish more in life. But new researches indicate that person's emotional and spiritual intelligence might be a greater predictor of success than his/her intellectual intelligence. Although it has been noticed that spiritual practices like mindful meditation, non-attachment and compassion can be used to reduce stress in the workplace, relatively limited research has been conducted on the effects of spiritual quotient on employee' performance in the workplace. The intent of the current quantitative phenomenological research study was to explore the lived experiences of employees to better understand the effect of using spiritual practices in attempting to manage performance in the workplace.

In increasingly competitive times, where customer demands are high, where the global marketplace is rapidly expanding, and where change appeared to be the only constant, many organizations are, emphasizing the importance of its employees. These organizations believe in „Our people are our most important assete. But what is meant in these phrases by the term ,people e? Considering people as a whole or is it just referred to their emotional, rational intelligence, their skills likewise. Are organizations looking forward to people who can be loaded with requisite information and can accordingly take the decision or people who can blend their experience, intelligence and add value of spirituality in taking the decisions and can be an exemplar (Srivastana \& Misra, 2012).

People with permanent employees status are reported to spend much of their time at work, or in work- related social and leisure activities and some have less time for anything else. However, according to Sharabi (2009), a majority of employees wants to find meaning in their work. As a result, although working people have desire to fulfil their spiritual requirement they are unable to do so because of time constraints. In response to this, many organisations started to focus on creating a work environment that brings a greater sense of meaning and purpose. Many corporations are encouraging the development of this new trend because they believe a humanistic work environment creates a win- win situation for both employees and the organization. 
Based on the background and the results of the identification of the problem, the formulation of the problem is:

1. Does emotional spiritual quotient positively affect performance?

2. Does employment status positively affect performance?

3. Do emotional spiritual quotient, and employment status simultaneously affect performance?

\section{Literature REVIEW}

Zohar and Marshall (2001) defined spiritual intelligence (spiritual quotient) as the intellectual ability to question why we are here and to be creative in our pursuit of answers. Thus, spiritual intelligence involves the cognitive processes resulting in both social modifications and consciousness transformations. Emmons \& Shelton (2002) defined spiritual intelligence as the adaptive use of spiritual information to facilitate everyday problem solving and goal attainment. Intelligence is the implementation of a set of tools to arrive at a more productive, effective, happier, and ultimately more meaningful life. Spiritual intelligence is thus a mechanism by which people can improve their overall quality of life. It is the application of a domain of knowledge to problems in living (Kumar and Pragadeeswaran, 2011).

The spiritual dimension of organizational life has been explored more formally through research. Duchon and Plowman (2005) demonstrated that work unit performance is positively associated with work unit spirituality. Dent, Higgins and Wharff (2005) reviewed 85 scholarly articles and found that most of them hypothesized a correlation between productivity and spirituality. They have pointed out the need for "a comprehensive and integrated theory of leadership that acknowledges leaders as complex beings who mature and develop over time in relationship to spiritual, emotional, cognitive, social, and physical domains". Marty (2003) believed "spirituality has become an advertised instrument for helping individuals cope with and interpret their place in the stressed world business and commerce". According to Fulton (2005) spiritual quotient also lead to an enhanced ability to find joy in the small things in life and make it easier to remain focused.

Employment status is a major determinant of the exchange relationship between individuals and the employing organisation (Wilson et al., 2008). The literature suggests that casual employment does not measure up well on many dimensions of security that constitute permanent employment (Paramio and Zofío, 2008). For instance, evidence suggests that casual workers have less opportunities for training, apprenticeship and education to acquire and refine capabilities and to make use of capabilities compared to permanent workers (Wickramasinghe \& Chandrasekara, 2011).

The employment arrangements in Indonesia are of different types. The permanent employment arrangement, which can be best understood as a contract for an indefinite term, is the central form. The permanent employment has been installed in Indonesia as both dominant form of employment and as the standard entry- point for access to a comprehensive set of industrial rights and benefits (Comola \& De Mello, 2011). Outside this framework lays nonstandard employment arrangements, such as, casual, probationary, seasonal, fixed- term and that of an apprentice. Casual employment arrangement is widely recognized in Indonesia as one of the main forms of nonstandard waged work.

A casual worker is one employed by chance and they will be offered work as and when work is available. An employer cannot expect a casual worker to arrive work continuously: casual worker can report for work as and when he/she desires. Further, casual workers cannot as of a right expect work from the employer. They are seen as workers who are used "as and when required", with each engagement being seen as a separate engagement. Furthermore, although permanent workers have a period of notice in the termination of employment, casual workers can be terminated or fail to be re- engaged at any time. By its very nature, casual employment cannot confer upon a workman a right to reinstatement as there is no former position in which he/she can be restored as in the case of a permanent worker (Gallaway \& Bernasek, 2002).

Based on above description, hypothesis formulated is: emotional spiritual quotient significantly affects performance (H1), employment status significantly affects performance (H2), emotional spiritual quotient and employment status simultaneously affect performance (H3). 


\section{Data Collection}

Descriptive statistics and quantitative analysis are used for finding initial solution to the problem encountered. The sample of this study were 100 permanent employees of Indonesia Port Corporation II located in Surabaya, East- Java Indonesia.

Techniques of data collection in this study is in the form of questionnaire. The normality assumption is prerequisites to proceed to further test. Analysis is conducted with multiple linear regression and hypothesis testing is performed at a significance level of 0.05 .

\section{RESUlt AND DiscuSSION}

The teachers of listed organisations were asked to participate in the survey by responding their opinions for three different measures in emotional spiritual quotient, employment status and performance. The normality is performed with Lilliefors test. Data are normally distributed as the value of each variable is not exceeding the critical value for Lilliefors test. The Lilliefors normality test values for product, price, distribution to freight forwarder choice are $0.052,0.061$ and 0.063 respectively below the critical value of 0.093 for $n=100$.

\subsection{The Effect of Emotional Spiritual Quotient to Performance}

Hypothesis testing confirms that emotional spiritual quotient positively affects performance with correlation coefficient value of 0.639 and the coefficient of determination $=0.408$. This means that $40.8 \%$ of employees' performance is determined by emotional spiritual quotient while the other $59.2 \%$ is contributed by other variables.

This finding is in line with Dunchon \& Plowman (2005) who defined workplace spirituality as a workplace that recognizes that employees have an inner life that is nourished by meaningful work that takes place in the context of community. In their exploratory study of six work units in a large hospital system, their finding results led to propositions concerning the effect of work unit spirituality on work unit performance and the relationship between work unit spirituality and leadership. Among medical units within the same hospital system, work unit spirituality is greater in some than in others; work unit performance is associated with work unit spirituality; and work unit leaders likely have an impact on the degree to which work units acknowledge and encourage issues of the spirit.

In context of Indonesia, this finding support Supriyanto \& Troena (2012) who examine, test, and evaluate the influence of emotional quotient and spiritual transformational leadership on job satisfaction, and performance in samples of 65 shariah banking managers. The result shows that emotional quotient significantly influences transformational leadership, emotional quotient significantly influences job satisfaction, emotional quotient significantly influences performance,

spiritual quotient significantly influence transformational leadership, spiritual quotient significantly influences job satisfaction, spiritual quotient significantly influences performance.

Thus, this finding strengthens the previous research on the effect of emotional spiritual quotient to job performance.

\subsection{The Effect of Employment Status to Performance}

Hypothesis testing confirms that employment status affects performance with the correlation coefficient value of 0.552 and coefficient of determination $=0.304$. This means that $30.4 \%$ of performance is determined by employment status while the other $69.6 \%$ is contributed by other variables.

This is consistent with Wickramasinghe \& Chandrasekar (2011) who investigate whether permanent workers with standard employment that is protected and casual workers with long-term employment that is not protected but performing the same core jobs along with permanent workers side-by-side in the same work setting exhibit different work-related outcomes. Job satisfaction, procedural justice and work performance were found as important work-related outcomes that discriminate between permanent and casual workers. If organisations use casual workers alongside permanent workers in core jobs, there is a need of examining implications of such practices.

Previous study in Indonesia also has shown that employment status has a positive relationship, to performance e.g., Dahesihsari, R. (2007). This research project is designed to investigate Indonesian employees' perceptions of Multi National Corporations (MNCs). More specifically, it examines the 
role of cultural differences and social identity in employees' perceptions of MNCs and psychological climate, the mediating role of their perceptions of managers' communications behaviour, and the impact of these on organisational identification and employee outcomes. The research provides evidence that cultural differences and social identity influenced Indonesian employees' perceptions of MNCs and psychological climate, leading to differences in organisation identification and employee outcomes.

Thus, this finding strengthens the previous research on the effect of employment status (identity) to job performance.

\subsection{Interaction of Emotional Spiritual Quotient and Employment Status to Performance}

When tested together, hypothesis testing results show that there is a significant relationship among emotional spiritual quotient and employment status to performance. The regression equation generated is $\hat{Y}=308,95+0,924 \mathrm{X} 1+0,280 \mathrm{X} 2$ with correlation of coefficient values $=0.932$ and the coefficient of determination $=0.868$. This means that $86.8 \%$ of performance is caused by variables of emotional spiritual quotient and employment while $13.2 \%$ is contributed by other variables not included in the model. This study adds to the body of research that has already considered emotional and spiritual intelligences but distinguishes itself from prior studies by considering emotional and spiritual intelligences in the work environment together, attempting to ascertain whether there are identifiable mixes of emotional and spiritual intelligences and considering the distinct and combined effects of these two forms of intelligence on performance. This study also provides some insight into the Indonesian work context in this regard.

\section{Conclusion}

The findings reveal that there is a positive and significant direct effect of emotional spiritual quotient and employment status to performance. Based on the initial design of the constellation between variables, the results showed that the contribution of emotional spiritual quotient to performance is $40.8 \%$ and employment status is $30.4 \%$, indicating the highest individual contribution to the employees, performance in among employees of Indonesia Port Corporation II is emotional spiritual quotient. When combined together, a contribution of the two variables of emotional spiritual quotient and employment status reaches $86.8 \%$ indicating the contribution of other variables not included in the model to predict performance is $13.2 \%$ indicating this model is of good-fit. However, other researchers wishing to conduct similar studies may include other variables such as; performance incentives, human resources development, allowance system, and work commitment.

\section{REFERENCES}

Comola, M., \& De Mello, L. (2011). How does decentralized minimum wage setting affect employment and informality? The case of Indonesia. Review of Income and Wealth, 57(s1), S79S99.

Dahesihsari, R. (2007). Employees' perceptions of multinational organizational practices in Indonesia: cultural differences and social identity. Doctoral Thesis. School of Psychology, University of Queensland.

Dent, E. B., Higgins, M. E., \& Wharff, D. M. (2005). Spirituality and leadership: An empirical review of definitions, distinctions, and embedded assumptions. The leadership quarterly, 16(5), 625-653.

Duchon, D., \& Plowman, D. A. (2005). Nurturing the spirit at work: Impact on work performance. The leadership quarterly, 16(5), 807-833.

Emmons, R. A., \& Shelton, C. M. (2002). Gratitude and the science of positive psychology. Handbook of positive psychology, 18, 459-471.

Gallaway, J. H., \& Bernasek, A. (2002). Gender and informal sector employment in Indonesia. Journal of Economic Issues, 36(2), 313-321.

Paramio, J. L., \& Zofío, J. L. (2008). Labor market duality and leisure industries in Spain: Quality of life versus standard of living. American Journal of Economics and Sociology, 67(4), 683-717.

P.R. Fulton, (2005.) Mindfulness as clinical training, in C. K. Germer, R. D. Siegel, \& P. R. Fulton (Eds.), Mindfulness and psychotherapy. New York: Guilford Press, pp.55-72.

Kumar, T., \& Pragadeeswaran, S. (2011). Effects of occupational stress on spiritual quotient among executives. International Journal of Trade, Economics and Finance, 2(4), 288. 
Marty, M. E. (2003). Non-religion, religion, and spirituality: Competing for business. Business, religion, and spirituality: A new synthesis, 31-52.

Sharabi, M. (2009). Work values, employment and ethnicity: Jewish and Muslim academic graduates in Israel. Cross Cultural Management: An International Journal, 16(4), 398-409.

Srivastava, A., \& Misra, S. (2012). Is Spiritual Quotient a better tool of success: Spirituality in the new world order. EXCEL International Journal of Multidisciplinary Management Studies, 2(1).

Supriyanto, A. S., \& Troena, E. A. (2012). Pengaruh Kecerdasan Emosional dan Kecerdasan Spiritual terhadap Kepemimpinan Transformasional, Kepuasan Kerja dan Kinerja Manajer (Studi di

Bank Syari’ah Kota Malang)'.Jurnal Aplikasi Manajemen, 10(4), 693-17.

Wickramasinghe, V., \& Chandrasekara, R. (2011). Differential effects of employment status on workrelated outcomes: A pilot study of permanent and casual workers in Sri Lanka. Employee Relations, 33(5), 532-550.

Wilson, J. M., O'Leary, M., Metiu, A., \& Jett, Q. R. (2008). Perceived Proximity in Virtual Work:: Explaining the Paradox of Far-but-Close. Organization Studies.

Zohar, D., \& Marshall, I. (2001). SQ: memanfaatkan kecerdasan spiritual dalam berpikir integralistik aan holistik untuk memaknai kehidupan. Mizan. 